\title{
PENGEMBANGAN ELEKTRODA PASTA KARBON TERMODIFIKASI MOLECULARLY IMPRINTED POLYMER SEBAGAI SENSOR POTENSIOMETRI UNTUK ASAM URAT
}

\author{
Miratul Khasanah*, Handoko Darmokoesoemo, Nesti Widayanti \\ Department of Chemistry, Faculty of Science and Technology, \\ Airlangga University \\ *email: miratulkhasanah@gmail.com
}

\author{
Received June 122016 \\ Accepted 30 November 2016
}

\begin{abstract}
Abstrak
Pengembangan elektroda pasta karbon/molecularly imprinted polymer (MIP) sebagai sensor untuk analisis asam urat secara potensiometri telah dilakukan. MIP dibuat dari monomer metil metakrilat, cross-linker etilen glikol dimetakrilat, dan asam urat sebagai template. Elektroda yang memberikan kinerja optimum dibuat dengan komposisi karbon, MIP, dan parafin 40:25:35(\%b/b). Pengukuran larutan asam urat dilakukan pada $\mathrm{pH}$ optimum 5. Kinerja elektroda dinyatakan dengan nilai faktor Nernst sebesar 30,19 $\mathrm{mV} /$ dekade dengan jangkauan pengukuran $10^{-6}-10^{-3} \mathrm{M}$, koefisien variasi 1,36-2,03\%,

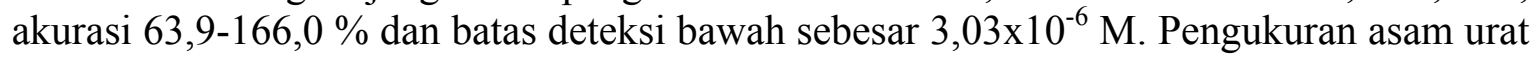
dengan elektroda ini tidak diganggu oleh keberadaan urea yang ditunjukkan dengan nilai koefisien selektivitas (Kij) kurang dari satu. Elektroda ini memiliki waktu respon kurang dari dua menit dan waktu hidup selama delapan minggu dengan 104 kali pemakaian.
\end{abstract}

Kata kunci: elektroda pasta karbon, MIP, potensiometri, asam urat

\begin{abstract}
Carbon paste electrode modified molecularly imprinted polymer (MIP) as a sensor to analyze uric acid by potentiometry has been developed. MIP was synthesized by mixing methyl methacrylate as monomer, etylene glycol dimethacrylic acid as cross-linker, and uric acid as template. The electrode which showed the best performance was manufactured by ratio of carbon, MIP, and paraffin of 40:25:35 (w/w). The developed electrode showed the optimum performance on the uric acid $\mathrm{pH}$ 5. The performances of carbon paste/MIP electrode was expressed by Nernst factor of $30.19 \mathrm{mV} / \mathrm{decade}$, measurement range of $10^{-6}$ $10^{-3} \mathrm{M}$, the coefficient of variation (CV) of $1.36-2.03 \%$ and accuracy of $63.9-166.0 \%$. The detection limit of this method was $3.03 \times 10^{-6} \mathrm{M}$. Analysis of uric acid using the electrode was not interfered by urea. The developed electrode showed the response time less than 2 minutes, while lifetime of the electrode was 8 weeks (104 times usage).
\end{abstract}

Keywords: carbon paste electrode, MIP, potentiometry, uric acid

\section{Pendahuluan}

Asam urat merupakan produk akhir metabolisme purin dalam tubuh manusia. Kadar normal asam urat dalam darah pria berada pada kisaran 3,4-7,0 $\mathrm{mg} / \mathrm{dL}$, sedangkan pada wanita berada pada kisaran 2,4-5,7 mg/dL. Kadar asam urat yang melebihi batas normal di dalam 
tubuh dapat menyebabkan berbagai penyakit diantaranya hiperurisemia, gout, leukimia, dan pneumonia (Ren et al., 2006), sehingga pengontrolan kadar asam urat harus dilakukan sejak dini agar dapat dilakukan pencegahan timbulnya penyakit berbahaya tersebut. Dalam bidang kedokteran, penentuan kadar asam urat umumnya dilakukan dengan metode kolorimetri menggunakan pereaksi kimia atau melalui reaksi enzimatik (Chen et al., 2005), high performance liquid chromatography (HPLC) (George et al., 2006), dan voltammetri (Chen et al., 2010; Khasanah et al., 2013). Metode analisis secara kolorimetri memerlukan sekitar 2-3 mL sampel darah, memiliki sensitivitas rendah, dan limit deteksi yang relatif tinggi yaitu skala $\mathrm{mM}$ ). Metode HPLC memerlukan waktu analisis yang lama, preparasi sampel rumit dan biaya operasional instrumen yang mahal. Sedangkan kelemahan metode voltammetri untuk analisis asam urat adalah adanya gangguan dari senyawa lain yang memiliki potensial oksidasi sangat dekat dengan asam urat pada berbagai jenis elektroda yang digunakan (Prekumar and Khoo, 2005).

Analisis asam urat secara voltammetri menggunakan sensor HMD termodifikasi molecularly imprinting polymer (HMDMIP) telah dikembangkan sebelumnya (Chen et al., 2010; Khasanah et al., 2010). Dengan sensor berbasis imprinting polimer ini diperoleh peningkatan selektivitas dan sensitivitas lebih dari 100 kali dibandingkan sensor HMD tanpa modifikasi (Khasanah et al., 2010 $0^{\mathrm{a}, \mathrm{b}}$ ). Penggunaan imprinting zeolit sebagai material modifier pada pembuatan sensor voltammetrik berbasis glassy carbon (GC) untuk analisis asam urat juga telah dipelajari. Metode yang dikembangkan memiliki batas deteksi $0,0454 \mathrm{ppb}$ $\left(2,7.10^{-10} \mathrm{M}\right)$. Nilai batas deteksi ini sekitar $10^{4}$ kali lebih rendah jika dibandingkan menggunakan metode spektrofotometri yang umum digunakan di bidang medis yaitu $1,2 \times 10^{-5} \mathrm{M}$.
Keberadaan asam askorbat, kreatin, kreatinin, glukosa dan urea relatif tidak mengganggu analisis asam urat. Sensor GC-IZ memiliki waktu hidup yang pendek yaitu hanya sekali pakai karena zeolit tidak dapat menempel permanen pada permukaan elektroda GC (tidak dapat membentuk komposit) (Khasanah et al., 2013).

Metode elektrometri lain yang dikembangkan untuk mendeteksi senyawa elektroaktif dalam cairan biologis adalah potensiometri. Ali et al. (2011) telah mengembangkan metode penentuan asam urat secara potensiometri menggunakan elektroda kawat nano $\mathrm{ZnO}$. Waktu respon dan jangkauan pengukuran yang dihasilkan adalah 6,25 detik dan $1,0 \times 10^{-6}-6,5 \times 10^{-4}$ M. Ali et al. (2012) juga telah mengembangkan sensor berbasis $\mathrm{ZnO}$ nanoflakes terimobilisasi enzim uricase untuk analisis asam urat. Hasil penelitian menunjukkan bahwa sensor yang dikembangkan memiliki jangkauan pengukuran $5,0 \times 10^{-7}-1,5 \times 10^{-}$ ${ }^{3} \mathrm{M}$ dan batas deteksi $5 \times 10^{-7} \mathrm{M}$. Sensor tidak diganggu oleh keberadaan asam askorbat, glukosa dan urea

Pada penelitian ini dilakukan pengembangan metode sederhana dengan selektivitas dan sensitivitas yang tinggi yaitu metode potensiometri melalui modifikasi elektroda menggunakan molecularly imprinted polymer (MIP). MIP dibuat dari metil metakrilat sebagai monomer, asam urat sebagai template, etilen glikol dimetakrilat sebagai crosslinker, dan benzoil peroksida sebagai inisiator. Perbandingan mol antara template, monomer, cross-linker, dan inisiator adalah 1:1:3 (Khasanah et al., 2012). Diharapkan dengan teknik MIP ini akan diperoleh suatu elektroda dengan cetakan yang hanya selektif terhadap asam urat

\section{Metode Penelitian \\ Alat dan Bahan}

Bahan-bahan yang digunakan pada penelitian ini adalah asam urat, metil 
metakrilat, etilen glikol dimetakrilat, benzoil peroksida, kloroform, natrium hidroksida, asam asetat glasial, metanol, natrium asetat trihidrat, natrium hidrogenfosfat dihidrat, natrium dihidrogenfosfat dihidrat, urea, serbuk karbon, kawat perak, parafin padat, asam klorida, n-heksana, etanol, dan ammonium asetat. Semua bahan kimia yang digunakan memiliki derajat kemurnian pro analisis (p.a). Air yang digunakan adalah akuades.

Peralatan yang digunakan adalah seperangkat alat potensiometer Cyberscan 510, elektroda pembanding $\mathrm{Ag} / \mathrm{AgCl}$, pH-meter tipe 744, corong Buchner, mikropipet, hotplate-magnetic stirrer, tube/tip mikropipet, serta peralatan pendukung lain.

\section{Prosedur Penelitian}

Pembuatan Molecularly Imprinted Polymer (MIP)

Molecularly Imprinted Polymer (MIP) dibuat dengan mencampurkan monomer, inisiator, cross-linker dan template dengan perbandingan mol hasil penelitian sebelumnya (Khasanah et al., 2012). Pada campuran metil metakrilat dan asam urat ditambahkan campuran cross-linker dan inisiator, kemudian dipanaskan pada suhu $60^{\circ} \mathrm{C}$ tanpa pengadukan hingga terbentuk padatan. Padatan yang terbentuk kemudian dikeringkan pada udara terbuka. Padatan ini disebut NIP (non imprinted polymer). Padatan selanjutnya digerus dan diayak dengan ayakan ukuran 200 mesh. Serbuk hasil sintesis dicuci menggunakan campuran asam asetat dan metanol dengan perbandingan 1:1. Setelah itu molekul template diekstraksi melalui sentrifugasi selama 15 menit menggunakan $10 \mathrm{~mL}$ ammonium asetat 1 M (dalam pelarut etanol, asam asetat dan air dengan perbandingan 40: 25: 35) (Moral and Mayes, 2004) sehingga diperoleh MIP. MIP dicuci dengan air kemudian disaring dan dikeringkan dalam oven. Polimetil metakrilat (PMMA) sebagai polimer kontrol disintesis dengan cara yang sama namun tanpa penambahan template (asam urat).

\section{Pembuatan elektroda pasta karbon/MIP}

Elektroda dibuat dengan mengisi $3 / 4$ bagian tube mikropipet (yang di dalamnya telah dipasang kawat Ag) dengan lelehan parafin. Bagian yang tersisa pada tube mikropipet diisi dengan campuran yang terdiri atas parafin padat, karbon, dan MIP. Campuran tersebut sebelumnya telah dipanaskan terlebih dahulu agar membentuk pasta, selanjutnya pasta dimasukkan ke dalam bagian yang tersisa pada tube mikropipet dan dibantu dengan penekanan agar padat dan terisi penuh. Permukaan elektroda digosok dengan kertas HVS agar rata dan halus. Elektroda yang telah dibuat digunakan untuk mengukur potensial larutan asam urat $10^{-8}-10^{-2} \mathrm{M}$. Elektroda yang menghasilkan jangkauan pengukuran yang luas dan faktor Nernst yang bagus merupakan elektroda dengan komposisi optimum.

\section{Optimasi pH larutan asam urat}

Ke dalam sederetan larutan asam urat konsentrasi tertentu ditambahkan larutan bufer asetat atau fosfat dengan $\mathrm{pH}$ 4-8. Kemudian masing-masing larutan dianalisis secara potensiometri menggunakan sensor pasta karbon/MIP yang disintesis dengan komposisi optimum. $\mathrm{pH}$ larutan yang memberikan sinyal potensial yang besarnya konstan disebut sebagai $\mathrm{pH}$ optimum.

\section{Uji validitas metode}

Dibuat sederetan larutan standar asam urat dengan konsentrasi $10^{-8}-10^{-3}$ $\mathrm{M}$ dan $\mathrm{pH}$ optimum, kemudian dianalisis secara potensiometri menggunakan sensor pasta karbon/MIP dengan komposisi optimum. Dilakukan replikasi sebanyak 3 kali. Dibuat kurva hubungan antara log konsentrasi asam urat dan besarnya potensial yang teramati untuk masing-masing konsentrasi asam urat yang dianalisis. Selanjutnya data hasil 
pengukuran larutan standar tersebut digunakan untuk menguji validitas metode meliputi jangkauan pengukuran, linieritas kurva kalibrasi, faktor Nernst, akurasi, presisi dan batas deteksi.

Selektivitas sensor dipelajari melalui penambahan komponen yang umum terdapat dalam sampel serum yaitu urea. Ke dalam larutan asam urat ditambahkan larutan urea dengan perbandingan konsentrasi asam urat dan urea bervariasi, kemudian respon potensial yang diperoleh dibandingkan dengan respon potensial hasil analisis asam urat tanpa penambahan urea dan dilakukan penghitungan koefisien selektivitas (Kij) untuk masing-masing penambahan konsentrasi urea.

Uji waktu respon dan waktu hidup (life time) sensor

Waktu respon sensor diamati dari 1-30 menit. Ketahanan dan waktu hidup sensor dipelajari melalui penyimpangan kinerja elektroda (terutama jangkauan pengukuran dan factor Nernst) yang dihasilkan setelah sensor digunakan untuk analisis sederetan larutan standar asam urat secara berulang-ulang dan dalam rentang waktu yang lama.

Tabel 1 Nilai faktor Nernst, jangkauan pengukuran, dan linieritas pada pengukuran larutan asam urat pada berbagai komposisi pembuatan elektroda

\begin{tabular}{ccccc}
\hline elektroda & $\begin{array}{c}\text { C:MIP:parafin } \\
(\% \mathrm{~b} / \mathrm{b})\end{array}$ & $\begin{array}{c}\text { jangkauan } \\
\text { pengukuran }(\mathrm{M})\end{array}$ & $\begin{array}{c}\text { faktor Nernst } \\
(\mathrm{mV} / \text { dekade })\end{array}$ & linieritas (r) \\
\hline E1 & $65: 0: 35$ & $10^{-6}-10^{-3}$ & 14,66 & 0,9946 \\
E2 & $60: 5: 35$ & $10^{-6}-10^{-3}$ & 14,18 & 0,9932 \\
E3 & $58: 7: 35$ & $10^{-6}-10^{-3}$ & 13,90 & 0,9682 \\
E4 & $55: 10: 35$ & $10^{-6}-10^{-3}$ & 14,35 & 0,9774 \\
E5 & $50: 15: 35$ & $10^{-6}-10^{-3}$ & 15,16 & 0.9853 \\
E6 & $45: 20: 35$ & $10^{-6}-10^{-2}$ & 18,94 & 0,9975 \\
E7 & $40: 25: 35$ & $10^{-6}-10^{-3}$ & 19,33 & 0,9960 \\
\hline
\end{tabular}

\section{Hasil dan Pembahasan}

Elektroda kerja adalah bagian terpenting dari potensiometer dan berfungsi sebagai sensor dari analit yang akan dianalisis. Sebelum dilakukan pengukuran dengan potensioemeter, terlebih dahulu dilakukan optimasi parameter analitik untuk memaksimalkan kinerja elektroda. Pada penelitian ini dilakukan dua macam optimasi, yaitu optimasi komposisi material penyusun elektroda dan optimasi $\mathrm{pH}$ larutan asam urat.

Optimasi komposisi elektroda dilakukan untuk mendapatkan elektroda yang mampu bekerja secara optimum. Pemilihan komposisi elektroda yang optimum didasarkan pada nilai faktor Nernst yang bagus, nilai linieritas mendekati satu serta jangkauan pengukuran yang luas. Menurut Cattrall (1997), metode potensiometri memenuhi persamaan Nernst apabila faktor Nernst bernilai $(59,2 / \mathrm{n} \pm 2) \mathrm{mV}$, dimana $n$ adalah valensi molekul. Asam urat yang merupakan molekul divalen sehingga faktor Nernst yang dihasilkan seharusnya adalah 29,6 $\mathrm{mV} /$ dekade. Berdasarkan pada Tabel 1 dapat dilihat bahwa elektroda yang menghasilkan faktor Nernst paling mendekati teoritis adalah E7 dengan jangkauan pengukuran $10^{-6}-$ $10^{-3} \mathrm{M}$ dan nilai linieritas 0,9906 .

Optimasi pH dilakukan untuk menentukan rentang $\mathrm{pH}$ yang menghasilkan nilai potensial yang stabil. Pengukuran dilakukan pada larutan asam urat $10^{-8}-10^{-3} \mathrm{M}$ dengan rentang $\mathrm{pH}$ 4-8 menggunakan E7. Berdasarkan Tabel 2 dapat dilihat bahwa larutan standar dengan $\mathrm{pH} 5$ menghasilkan nilai faktor Nernst yang paling bagus yaitu 27,02 $\mathrm{mV} /$ dekade dengan jangkauan 
pengukuran $10^{-6}-10^{-3} \mathrm{M}$ dan linieritas 0,9745 .

Hasil penentuan $\mathrm{pH}$ optimum menunjukkan bahwa perubahan $\mathrm{pH}$ mempengaruhi respon potensial yang dihasilkan. Pada $\mathrm{pH} 5$ potensial yang dihasilkan relatif konstan. Pada $\mathrm{pH}$ tersebut asam urat berada dalam bentuk molekul $(\mathrm{pKa}=5,45) \cdot \mathrm{pH}$ kerja yang selanjutnya digunakan untuk analisis asam urat menggunakan elektroda pasta karbon nanopori-MIP secara potensiometri adalah $\mathrm{pH} 5$.

Tabel 2 Nilai faktor Nernst, jangkauan pengukuran dan linieritas hasil pengukuran larutan asam urat menggunakan E7.

\begin{tabular}{cccc}
\hline $\mathrm{pH}$ & jangkauan pengukuran $(\mathrm{M})$ & faktor Nernst $(\mathrm{mV} /$ dekade $)$ & linieritas $(\mathrm{r})$ \\
\hline 4 & $10^{-6}-10^{-3}$ & 19,42 & 0,9829 \\
5 & $10^{-6}-10^{-3}$ & 27,02 & 0,9745 \\
6 & $10^{-6}-10^{-3}$ & 20,51 & 0,9992 \\
7 & $10^{-6}-10^{-3}$ & 18,44 & 0,9970 \\
8 & $10^{-6}-10^{-3}$ & 17,40 & 0,8942 \\
\hline
\end{tabular}

Selanjutnya dilakukan pembuatan elektroda pasta karbon termodifikasi poliMMA (EPMMA) dan non imprinted polimer (ENIP). Pembuatan EPMMA dan ENIP dilakukan dengan variasi perbandingan massa karbon nanopori, PMMA atau NIP, dan parafin padat sama dengan E7. Hal ini bertujuan untuk mengetahui pengaruh template asam urat terhadap sensitivitas elektroda. Pada penelitian ini didapatkan faktor Nernst, jangkauan pengukuran, dan linieritas pada masing-masing elektroda yang dapat dilihat pada Tabel 3.

Tabel 3. Nilai faktor Nernst, jangkauan pengukuran, dan linieritas pada pengukuran larutan standar asam urat menggunakan elektroda termodifikasi PMMA, NIP, dan MIP

\begin{tabular}{cccc}
\hline elektroda & $\begin{array}{c}\text { faktor Nernst } \\
(\mathrm{mV} / \text { dekade })\end{array}$ & $\begin{array}{c}\text { jangkauanpengukuran } \\
(\mathrm{M})\end{array}$ & $\begin{array}{c}\text { linieritas } \\
(\mathrm{r})\end{array}$ \\
\hline E7 & 27,02 & $10^{-6}-10^{-3}$ & 0,9745 \\
EPMMA & 15,20 & $10^{-6}-10^{-3}$ & 0,9907 \\
ENIP & 20,60 & $10^{-6}-10^{-3}$ & 0,9846 \\
\hline
\end{tabular}

Tabel 3 menunjukkan bahwa kinerja E7 lebih baik dibandingkan dengan EPMMA dan ENIP, dikarenakan E7 memiliki template yang sesuai dengan ukuran pori dan bentuk seperti molekul asam urat. Teknik imprinting menghasilkan pori material menyesuaikan ukuran analit sehingga analit dapat terperangkap ke dalam pori material, yang menyebabkan analit dapat dengan mudah terukur (Sellergren, 2001).

\section{Kinerja Sensor Pasta Karbon /MIP dan Validitas Metode}

Kinerja sensor pasta karbon/MIP dinyatakan dengan nilai waktu respon dan waktu hidup (lifetime) sensor tersebut. Suatu sensor dikatakan semakin sensitif apabila waktu yang diperlukan untuk merespon analit semakin pendek (Gea et al., 2005). Pada penelitian ini penentuan waktu respon dilakukan dengan menggunakan konsentrasi jangkauan pengukuran yaitu $10^{-6} \mathrm{M}$ sampai $10^{-3} \mathrm{M}$. Kurva standar jangkauan pengukuran asam urat ditampilkan pada Gambar 3.

Gambar 3 menunjukkan nilai faktor Nernst sebesar 30,19 mV/dekade. Asam urat merupakan molekul divalen (Gambar 4) dengan demikian seharusnya memiliki harga faktor Nernst sebesar $(29,6 \pm 2)$ $\mathrm{mV} /$ dekade. 


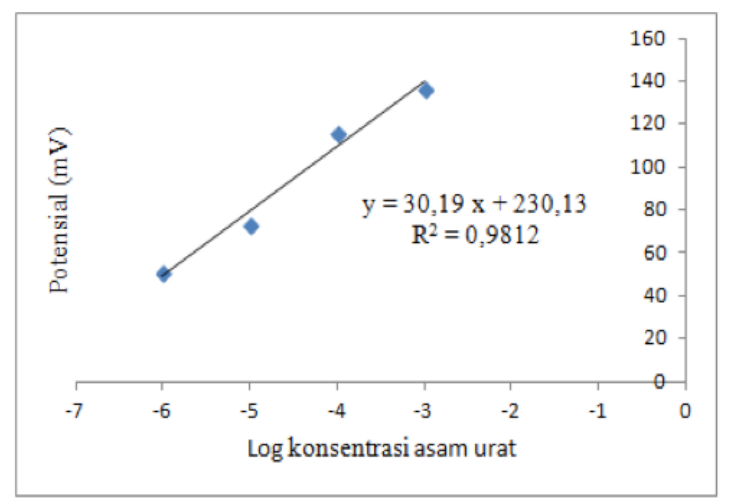

Gambar 3. Kurva standar asam urat

Kinerja suatu elektroda/sensor potensiometri dipelajari dengan menentukan jangkauan pengukuran, faktor Nernst, batas deteksi dan selektivitas. Pada penelitian ini dipelajari selektivitas elektoda terhadap asam urat dalam larutan yang mengandung urea. Kinerja elektroda secara keseluruhan ditampilkan pada Tabel 3.
Nilai presisi (koefisien variasi) yang diperoleh lebih bagus dari batasan yang ditetapkan oleh AOAC (Association of Official Analytical Chemist) yaitu 3,7$11,0 \%$ untuk konsentrasi $10^{-6}$ hingga $10^{-3}$ M (Taverniers et al., 2004), sedangkan nilai akurasinya masih kurang bagus. Nilai batas deteksi metode penentuan kadar asam urat secara potensiometri menggunakan elektroda pasta karbonMIP sekitar lima puluh kali lebih rendah dibandingkan dengan metode spektrofotometri yang selama ini digunakan di bidang medis yaitu $1,54 \times 10^{-}$ ${ }^{4} \mathrm{M}$ (Chen et al., 2005). Dengan demikian penentuan asam urat dalam serum menggunakan metode yang dikembangkan ini membutuhkan volume sampel serum yang lebih kecil dibandingkan metode spektrofotometri.

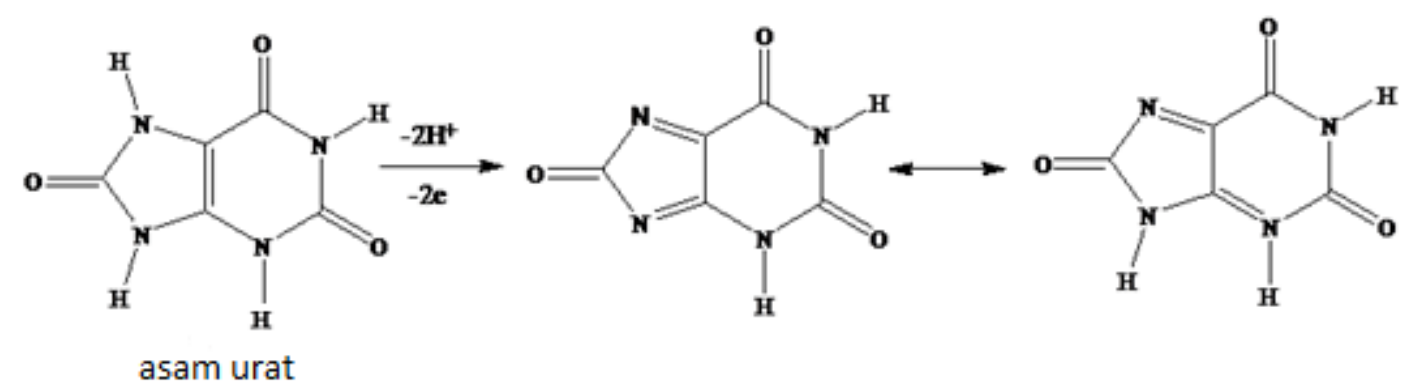

Gambar 4. Reaksi oksidasi asam urat (Huang et al., 2006)

Tabel 3 Kinerja elektroda

\begin{tabular}{cll}
\hline No & Parameter & Nilai \\
\hline 1 & Jangkauan pengukuran & $10^{-6}-10^{-3} \mathrm{M}$ \\
2 & Linieritas kurva kalibrasi & 0,9906 \\
3 & Faktor Nernst & $30,19 \mathrm{mV} /$ dekade \\
4 & Waktu respon & $32-60$ detik \\
5 & Batas deteksi (bawah) & $3,03 \times 10^{-6} \mathrm{M}$ \\
6 & Koefisien variasi & $1,36-2,03 \%$ \\
7 & Akurasi & $63,9-166,0 \%$ \\
8 & Lifetime & 104 kali pengukuran $(8$ minggu $)$ \\
9 & Selektivitas (Kij) & Selektif dlm matriks urea $(\mathrm{Kij}<1)$ \\
\hline
\end{tabular}




\section{Kesimpulan}

MIP yang terbuat dari monomer metil metakrilat dapat meningkatkan kinerja elektroda pasta karbon untuk analisis asam urat secara potensiometri. Elektroda pasta karbon-MIP bekerja optimum pada pH 5 dengan waktu respon kurang dari 2 menit dan memiliki selektivitas yang tinggi dalam matriks urea. Elektroda memiliki waktu hidup 8 minggu (104 kali pemakaian) dengan batas deteksi sekitar 50 kali lebih rendah dari konsentrasi normal asam urat dalam darah, sehingga

\section{Daftar Pustaka}

Ali, S.M. U., Alvi., N.H., Ibupoto, Z., Nur, O., Willander, M., and Danielsson, B., 2011, Selective potentiometric determined nation of uric acid with uricase immobilized on $\mathrm{ZnO}$ nanowires, Sens. Actuators B-Chemical, 2 (152), 241-247.

Ali, S.U., Ibupoto, Z.H., Kashif, M, Hashim, U. and Willander, M, 2012, A Potentiometric indirect uric acid sensor based on $\mathrm{ZnO}$ nanoflakes and immobilized uricase, Sensors, 12, 2787-2797.

Cattrall, R.W., 1997, Chemical Sensors, Oxford University Press, New York.

Chen, J.C., Chung, H.H., Hsu, C.T., Tsai, D.M., Kumar, A.S., and Zen, J.M., 2005, A disposable single-use electrochemical sensor for the detection of uric acid in human whole blood, Sens. Actuators B, 110, 364.

Chen, P., Vittal, R., Nien, P., Liou, G. and Ho, K., 2010, A novel molecularly imprinted polymer thin film as biosensor for uric acid, Talanta, 80, 1145-1151.

Gea, S., Andriyani, dan Lenny, S., 2005, Pembuatan Elektroda Selektif Ion $\mathrm{Cu}$ (II) dari Kitosan-Polietilen Oksida, Jurnal Penelitian, Unviversitas Sumatera Utara dapat diaplikasikan untuk analisis asam urat dalam sampel darah.

\section{Ucapan Terimakasih}

Penulis mengucapkan terimakasih kepada Kementerian Riset dan Dikti melalui Lembaga Penelitian dan Inovasi Universitas Airlangga yang telah memberikan pendanaan RUPT sesuai SK Rektor No. 584/UN3/2016 dan Departemen Kimia FST Universitas Airlangga yang telah memberikan fasilitas laboratorium.

George, S.K., Dipu, M.T., Mehra, U.R., Singh, P., Verma, A.K. and Ramgaokar, J.S., 2006, Improved HPLC method for the simultaneous determination of allantonin, uric acid, and creatinine in cattle urine, Journal of Chromatography B, 832: 134-137

Huang, X, Im H., Yarimaga, O., Kim, J., Lee, D., Kim, H. and Choi, Y., 2006, Direct Electrochemistry of uric acid at chemically assembled carboxylated single-walled carbon nanotubes netlike electrode, J. Phys. Chem. B, 110, 21850-21856

Khasanah, M., Harsini, M., and Widati, A.A., 2013, Imprinting zeolite modified glassy carbon as a voltammetric sensor for uric acid, Indo. J. Chem, 13 (2), 108-113.

Khasanah, M., Mudasir, Kuncaka, A. and Sugiharto, E., 2012, Development of uric acid sensor based on molecularly imprinted polymethacrylic acidmodified hanging mercury drop electrode, J. Chem. Chem. Eng., 6, 209-214.

Khasanah, M., Supriyanto, G., Tambunan, F.N., Mudasir, Kuncaka, A. and Sugiharto, E., 2010 a, Molecularly imprinted polymethacrylic acid modified glassy carbon as a voltammetric sensor of uric acid analysis, Proceeding on the $2^{\text {nd }} I C C S$, UGM, Yogyakarta, p. 457-460. 
Khasanah, M., Supriyanto, G., Wafiroh, S., Kuncaka, A., Sugiharto, E, and Mudasir, 2010 ${ }^{\mathrm{b}}$, Enhancement of the sensitivity and selectivity of the voltammetric sensor for uric acid using molecularly imprinted polymer, Indo. J. Chem., 10 ( 3), 295-300.

Moral, N.P. and Mayes, A.G., 2004, Comparative study of imprinted polymer particles prepared by different polymerisation methods, Anal. Chim. Acta, 504, 15-21.

Premkumar, J. and Khoo, S.B., 2005, Electrocatalytic oxidation of biological molecules (ascorbic acid and uric acid) at highly oxidized electrodes, J. Electroanal. Chem., 576, 105-112
Ren, W., Luo, H. Q. and Li, N.B., 2006, Simultaneous voltammetric measurement of ascorbic acid, epinephrine and uric acid at glassy carbon electrode modified with caffeic acid, Biosens. Bioelectron., 21, 1086-1092.

Sellergren, B. (Ed), 2001, Molecularly Imprinted Polymer: Man-made mimics of antibodies and their applications in analytical chemistry, Elsevier, Amsterdam.

Taverniers, I., De Loose, M., and Van Bockstaele, E., 2004, Trends in quality in the analytical laboratory. II. Analytical method validation and quality assurance, Trends Anal. Chem., 23 (8), 535-552 
